\title{
Diversity and genetic structure of mangabeira (Hancornia speciosa Gomes), a fruit species from Cerrado
}

\section{Diversidade e estrutura genética de mangabeira (Hancornia speciosa Gomes), uma fruteira do Cerrado}

\author{
Fabiano Silva Soares ${ }^{1 *}$; Ana Aparecida Bandini Rossi ${ }^{2}$; Bruna Mezzalira da Silva ${ }^{1}$; \\ Jakeline Santos Cochev ${ }^{3}$; Severino de Paiva Sobrinho ${ }^{4}$; Petterson Baptista da Luz ${ }^{4}$
}

\begin{abstract}
Hancornia speciosa Gomes, popularly known as mangabeira, is a fruit tree belonging to the Apocynaceae family, native to the Brazilian Cerrado. The fruit is widely used by the local population as an alternative source of income. Limited information is available about this species, which increases the difficulty of conserving its genetic resources and exploiting mangabeira as an economic resource. The objective of this research was to evaluate the genetic diversity and genetic structure of $H$. speciosa from Chapada dos Guimarães. Twenty-four trees and ten inter simple sequence repeats (ISSR) primers were evaluated. Of the 57 bands obtained, $33(57.89 \%)$ presented polymorphism. The analysis using Structure defined two different clusters $(K=2)$, which were consistent with the unweighted pair group method with arithmetic mean (UPGMA) clustering analysis. The number of observed alleles $(\mathrm{Na}=1.58)$, number of effective alleles $(\mathrm{Ne}=1.29)$, Nei's genetic distance $(\mathrm{He}=0.18)$ and Shannon index $(I=0.27)$ were considered low among the population. The analysis of molecular variance (AMOVA) revealed that the variability within the cluster (83.39\%) was higher than among clusters (16.61\%). ISSR primers proved effective for detection of genetic polymorphism in $H$. speciosa, and could be utilized for strategies that aim at conservation, plant breeding programs, and commercial use.
\end{abstract}

Key words: Mangaba. Molecular analysis. ISSR.

\section{Resumo}

Hancornia speciosa Gomes, conhecida popularmente como mangabeira, é uma fruteira pertencente à família Apocynaceae que ocorre espontaneamente no Cerrado brasileiro. O fruto da mangabeira é bastante utilizado pela população local como fonte alternativa de renda e sua exploração é feita de forma extrativista. As informações sobre esta espécie são escassas, o que dificulta a conservação dos recursos genéticos e sua exploração econômica. Neste trabalho foi estudada a diversidade e estrutura genética de uma população de mangabeira, tendo sido avaliada um total de 24 árvores matrizes localizadas em Chapada dos Guimarães-MT por meio de 10 primers ISSR (inter repetições de sequências simples) que revelaram 57 bandas. Destas, $33(57,89 \%)$ apresentaram polimorfismo. A análise utilizando o Structure definiu dois grupos diferentes $(K=2)$, resultados que foram consistentes com os da análise

\footnotetext{
${ }^{1}$ Mestres em Genética e Melhoramento de Plantas, Universidade do Estado de Mato Grosso, UNEMAT, Cáceres, MT, Brasil. E-mail: soares fabiano@hotmail.com; bruna mezzalira@hotmail.com

2 Prof ${ }^{\mathrm{a}} \mathrm{Dr}^{\mathrm{a}}$, Departamento de Ciências Biológicas, UNEMAT, Alta Floresta, MT, Brasil. E-mail: anabanrossi@gmail.com

3 Discente de Doutorado, Programa de Pós-graduação em Biodiversidade e Biotecnologia da Amazônia Legal/Rede Bionorte, UNEMAT, Alta Floresta, MT, Brasil. E-mail: jackcochev@gmail.com

4 Profs. Drs., Departamento de Agronomia, UNEMAT, Cáceres, MT, Brasil. E-mail: paivasevero@hotmail.com; petterbaptista@ yahoo.com

* Author for correspondence
}

Received: Nov. 29, 2016 Approved: May 19, 2017 
de agrupamento UPGMA. O número de alelos observados $(\mathrm{Na}=1,58)$, número de alelos efetivos $(\mathrm{Ne}$ $=1,29)$, índice de diversidade de Nei $(H e=0,18)$ e o índice de Shannon $(I=0,27)$ foram relativamente baixos dentro da população. A AMOVA revelou que a variabilidade dentro dos grupos $(83,39 \%)$ foi mais alta do que entre os grupos (16,61\%). A utilização de iniciadores ISSR mostrou-se eficaz para deteç̧ão de polimorfismo genético em mangabeira, servindo de aporte para estratégias que visem à conservação, melhoramento genético e exploração econômica da espécie.

Palavras-chave: Análise molecular. Mangaba. ISSR.

\section{Introduction}

Hancornia speciosa Gomes (Apocynaceae), popularly known as mangabeira, is a species native to the Brazilian Cerrado. Owing to its fruit, the mangaba, this tree is as an alternative source of family income for the local population. It has a potential for cultivation because it is easy to obtain the seeds and the species has adapted to grow in marginal soils. Some orchards designated for cultivation of mangabeira for commercial use are found in the midwestern and northeastern Brazilian (PEREIRA et al., 2010).

The plant is medium-sized, ranging from 5 to $15 \mathrm{~m}$ high, with an irregular canopy and numerous tortuous branches. The optimal vegetative growth is achieved during the period with high temperatures and annual rainfall between 750 and 1,600 mm. Considered a typical allogamous species, its flowers are hermaphrodite and self-incompatible. The flowering occurs during the rainy season (SILVA JUNIOR; LÉDO, 2006). Insects belonging to family Euglossinae, Hesperiidae, Urbaninae, Nymphalidae, Sphingidae, and Sphinginae families are the pollinators for this plant species (DARRAULT; SCHLINDWEIN, 2005).

Studies on the genetic diversity of mangabeira populations are scarce. The knowledge of the genetic structure of natural populations is essential for their domestication and breeding and for Genbank sampling, because it may directly affect the longterm viability of the population (MOURA et al., 2011). Owing to the reduction of areas where our study species occurs naturally, i.e., the Cerrado and the Atlantic Forest, the identification, collection, preservation, and characterization of the available genetic resources is of utmost importance (SILVA JUNIOR; LÉDO, 2006).

Molecular markers are widely used to evaluate the genetic variability in natural populations of plants (REDDY et al., 2002; SOARES et al., 2008; ZUCCHI et al., 2005). They are more advantageous than morphological markers because molecular markers are not affected by the environment and they present a high number of polymorphisms, allowing studies at any developmental stage of the plant (FALEIRO, 2007). Inter-simple sequence repeat (ISSR) is a useful tool to study genetic diversity and structure (JIMENEZ et al., 2015).

Therefore, the aim of this study was to use ISSR markers to evaluate the diversity and characterize the genetic structure of mangabeira from the Chapada dos Guimarães/MT.

\section{Material and Methods}

\section{Plant material and extraction of genomic DNA}

Young leaves from 24 mangabeira mother trees were collected in the Chapada dos Guimarães/MT (Figure 1) and stored at $-20^{\circ} \mathrm{C}$ in the Laboratory of Genetics and Molecular Biology of the University of Mato Grosso (UNEMAT) in Alta Floresta/Mato Grosso. DNA was extracted according to the CTAB protocol described by Doyle and Doyle (1987) with the following modifications to the extraction buffer: 5\% CTAB (100 mM of Tris- $\mathrm{HCl}, \mathrm{pH} 8 ; 20$ $\mathrm{mM}$ of EDTA, $\mathrm{pH} 8$; and $1.4 \mathrm{M}$ of $\mathrm{NaCl}), 1.5 \%$ $\beta$-mercaptoethanol, $4 \% \mathrm{PVP}$, and the addition of 3.5 $\mu \mathrm{L}$ of Proteinase K (20 $\left.\mathrm{mg} \mathrm{mL}^{-1}\right)$ per sample. 
The amount and integrity of DNA samples were verified on $1 \%$ agarose gel stained with ethidium bromide (10 $\left.\mathrm{mg} \mathrm{mL}^{-1}\right)$ and subjected to horizontal electrophoresis for approximately $2 \mathrm{~h}$ at $80 \mathrm{~V}$. DNA was visualized under UV light using a transilluminator and quantified by comparison with a known standard molecular weight using the bacteriophage $\lambda$ DNA (10 ng $\left.\mu \mathrm{L}^{-1}\right)$. Samples were diluted in autoclaved distilled water, standardized to a concentration of $5 \mathrm{ng} \mu \mathrm{L}^{-1}$, and stored at $-20^{\circ} \mathrm{C}$.

Figure 1. Distribution of 24 mangabeira mother trees in the sampled population in Chapada dos Guimarães/MT.

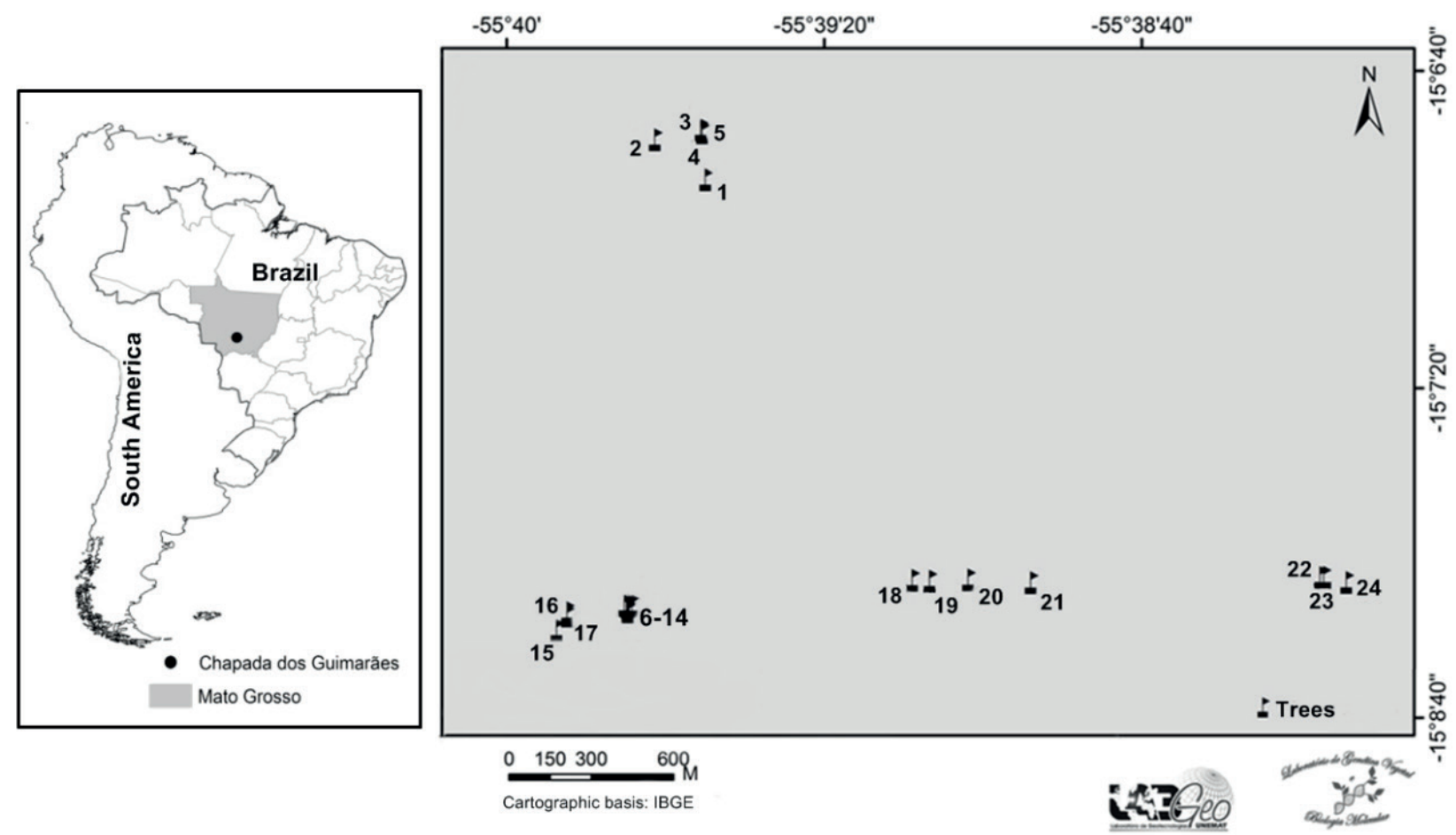

\section{PCR and electrophoresis}

Ten ISSR primers (University of British Columbia, Vancouver, Canada) were used for genomic DNA amplification. The mixture comprised $2.5 \mu \mathrm{L}$ of $10 \mathrm{X}$ buffer (without $\mathrm{Mg}^{++}$), $1 \mu \mathrm{L}$ of $\mathrm{MgCl}_{2}$ (50 mM), $1 \mu \mathrm{L}$ of DMSO (100\%), $1 \mu \mathrm{L}$ of dNTPs (1 mM each), $2 \mu \mathrm{L}$ of primer $(0.2 \mathrm{mM}), 0.12 \mu \mathrm{L}$ Taq polymerase $(5 \mathrm{U}), 2 \mu \mathrm{L}$ of genomic DNA (5 $\mathrm{ng}$ ) and autoclaved distilled water to a final volume of $25 \mu \mathrm{L}$. Amplification conditions were one initial denaturation for $4 \mathrm{~min}$ at $94^{\circ} \mathrm{C}$, followed by 35 cycles of denaturation at $94^{\circ} \mathrm{C}$ for $1 \mathrm{~min}$, annealing at 49.8 to $53^{\circ} \mathrm{C}$ for $1 \mathrm{~min}$, and extension at $72^{\circ} \mathrm{C}$ for $2 \mathrm{~min}$, plus a final extension step at $72^{\circ} \mathrm{C}$ for $7 \mathrm{~min}$.
Amplification products were separated on 2\% agarose gel stained with ethidium bromide and immersed in 1X TBE buffer ( $89 \mathrm{mM}$ Tris-base, 89 $\mathrm{mM}$ boric acid, and $2 \mathrm{mM}$ EDTA) for about $4 \mathrm{~h}$ at 80 V. The DNA ladder of $100 \mathrm{bp}$ (Kasvi) was used as a molecular weight standard. Gels were visualized in UV light and photographed using a digital camera.

\section{Statistical analysis}

The data of presence (1) and absence (0) of bands were used to estimate the genetic distance across the arithmetic complement of the Jaccard coefficient using the software Genes (CRUZ, 2013). The dendrogram of genetic dissimilarity based on 
the unweighted pair group method with arithmetic mean (UPGMA) hierarchical method was generated in the software R, version 3.2.4 (R CORE TEAM, 2016), with 1,000 simulations for a grouping consistency test.

The Bayesian analysis was performed using the software Structure (PRITCHARD et al., 2000). The number of $K$ clusters was adjusted to variations from 1 to 5, with 20 independent interactions, each using 250,000 burn-ins and 750,000 Markov chain Monte Carlo (MCMC) simulations. The genetic structure was analyzed using the software Structure Harvester (EARL; VONHOLDT, 2012) following criteria described by Evanno et al. (2005) for determining the optimal number of clusters. The genetic variation between clusters was calculated by Nei's genetic distance $(\mathrm{He})$ and Shannon index $(I)$ using the software Popgene (YEH et al., 1997). The analysis of molecular variance
(AMOVA) was calculated using the software Arlequin 3.5 (EXCOFFIER; LISCHER, 2010). The significance of differentiation was tested with 1,000 permutations, where $\mathrm{P}$ denotes the probability of observing a random value greater than or equal to the observed value.

\section{Results and Discussion}

The set of ISSR primers used produced 57 bands, 5.7 bands per primer, ranging from 2 (UBC 812) to 8 (UBC 809 and UBC 835) (Table 1). Among all amplified bands, 33 (57.89\%) were polymorphic, indicating that these markers may be used to distinguish mangabeira populations and trees. Studies with this species using the ISSR technique have detected $47.62 \%$ (COSTA et al., 2015) to $89.27 \%$ (JIMENEZ et al., 2015) of polymorphism.

Table 1. ISSR primers with their nucleotide sequences, annealing temperatures (Ta), total number of bands (TNB), polymorphic bands (PB), and percentage of polymorphic bands (PPB).

\begin{tabular}{cccccc}
\hline Primers & Sequence 5' $\rightarrow$ 3' & Ta $\left({ }^{\circ} \mathrm{C}\right)$ & TNB & PB & PPB (\%) \\
\hline UBC 807 & AGA GAG AGA GAG AGA GT & 49,8 & 5 & 3 & 60,0 \\
UBC 809 & AGA GAG AGA GAG AGA GG & 51,5 & 8 & 6 & 75,0 \\
UBC 810 & GAG AGA GAG AGA GAG AT & 50,0 & 7 & 3 & 42,8 \\
UBC 812 & GAG AGA GAG AGA GAG AA & 50,0 & 2 & 1 & 50,0 \\
UBC 818 & CAC ACA CAC ACA CAC AG & 52,5 & 3 & 2 & 66,7 \\
UBC 827 & ACA CAC ACA CAC ACA CG & 53,0 & 6 & 4 & 66,7 \\
UBC 834 & AGA GAG AGA GAG AGA GYT & 52,5 & 6 & 5 & 83,3 \\
UBC 835 & AGA GAG AGA GAG AGA GYC & 50,2 & 8 & 2 & 25,0 \\
UBC 841 & GAG AGA GAG AGA GAG AYC & 50,0 & 6 & 3 & 50,0 \\
UBC 891 & HVH TGT GTG TGT GTG TG & 50,4 & 6 & 4 & 66,7 \\
Total & & & 57 & 33 & \\
\hline
\end{tabular}

Based on the grouping by UPGMA, there was differentiation of mother trees from a dissimilarity of 0.02 (Figure 2), indicating a low genetic divergence among some mangabeira mother trees. Using mean genetic dissimilarity $(0.13)$, four similarity groups were established: G-1: 17 mother trees; G-2: one mother tree (1); G-3: four mother trees $(18,13,17$ and 14); and G-4: two mother trees (8 and 2).

The cophenetic correlation coefficient showed an association of $68 \%$ between the distances obtained by the Jaccard coefficient (dissimilarity matrix) and those represented in the dendrogram (cophenetic 
matrix). The cophenetic value observed was $r=0.68$

considered ideal, thus reflecting a consistency with $(\mathrm{p}<0.001)$, which is adequate as $r \geq 0.56$ values are

genetic similarity values (VAZ PATTO et al., 2004).

Figure 2. Dendrogram of 24 mangabeira mother trees, obtained by UPGMA, using the complement of the Jaccard similarity index from 10 ISSR primers. The value of the cophenetic correlation coefficient (r) is 0.68.

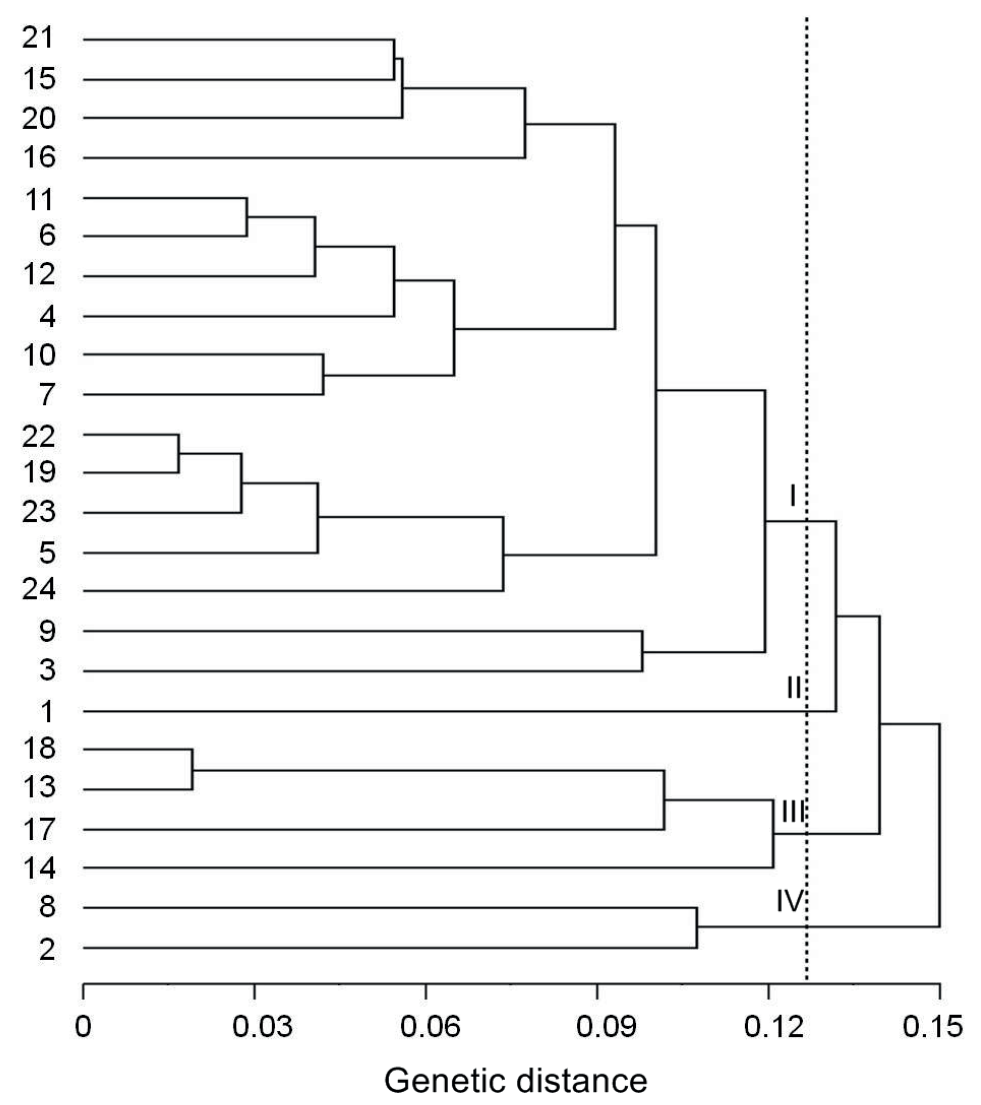

According to Bayesian analysis performed using the software Structure and in accordance with the $\Delta K$ method described by Evanno et al. (2005), the most likely number of clusters was $K=2$ (Figure 3-A). The graphic display of the population structure allowed the separation of mother trees into two clusters: Cluster I, which had 15 mother trees and Cluster II, which had nine mother trees (Figure 3-B). These results were consistent with the UPGMA grouping method, assuming that based on the genetic distance of 0.11 ( $70 \%$ similarity), the population is divided into two subpopulations.

A joint analysis of the information between the UPGMA grouping and the Bayesian analysis revealed a consistency in groupings using both methods. Structure Cluster I had the highest number of mother trees and was similar to the G1 in the dendrogram. The remaining mangabeira mother trees, except mother trees 9 and 3, were allocated to the Structure Cluster II, corresponding to the G-2, G-3 and G-4 groups of UPGMA. Therefore, it appears that there is a genetic diversity among the mangabeira population evaluated, because mother trees were not allocated to the same cluster by any of the grouping methods.

The Structure groupings did not reflect a geographical structure in relation to genetic diversity (Figures 1 and 3). It is also observed that more similar 
mangabeira mother trees (22 and 19, 18 and 13) were not the closest geographically (Figures 1 and 2 ). This similarity between geographically distant pairs can be explained by activities of humans and seed dispersers (OLIVEIRA et al., 2010).

The Nei's genetic distance $(\mathrm{He})$ for the two clusters formed by the software Structure was 0.18 . The observed number of alleles was 1.58 and the effective number of alleles was 1.29. The Shannon index (I) was 0.27 (Table 2). The values observed for $\mathrm{He}$ and $I$ indicate that there is a genetic diversity within the population. In their research with mangabeira, Silva et al. (2012), using molecular markers, found a value of 0.35 for $\mathrm{He}$ and a value of 0.46 for $I$. They concluded that the species showed a high genetic diversity. Costa et al. (2015), assessing the genetic diversity among mangabeira genotypes, found average values of 0.17 and 0.25 for $\mathrm{He}$ and $I$, respectively. This was similar to the values found in this study. Jimenez et al. (2015) observed absolute values for $\mathrm{He}$ ranging from 0.197 to 0.229 .

Figure 3. Distribution of $\Delta K$ probability. A. Estimated structure of the mangabeira population. B. Representation of 24 mangabeira mother trees divided into clusters according to molecular data using ISSR by the software Structure. Mother trees are represented by vertical bars with a coloring related to the group to which they belong (two clusters, $K=2)$.

A

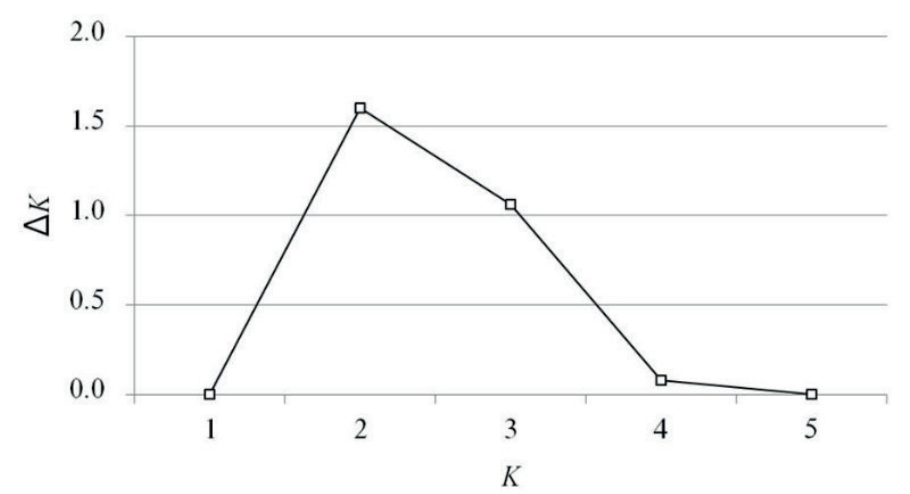

B

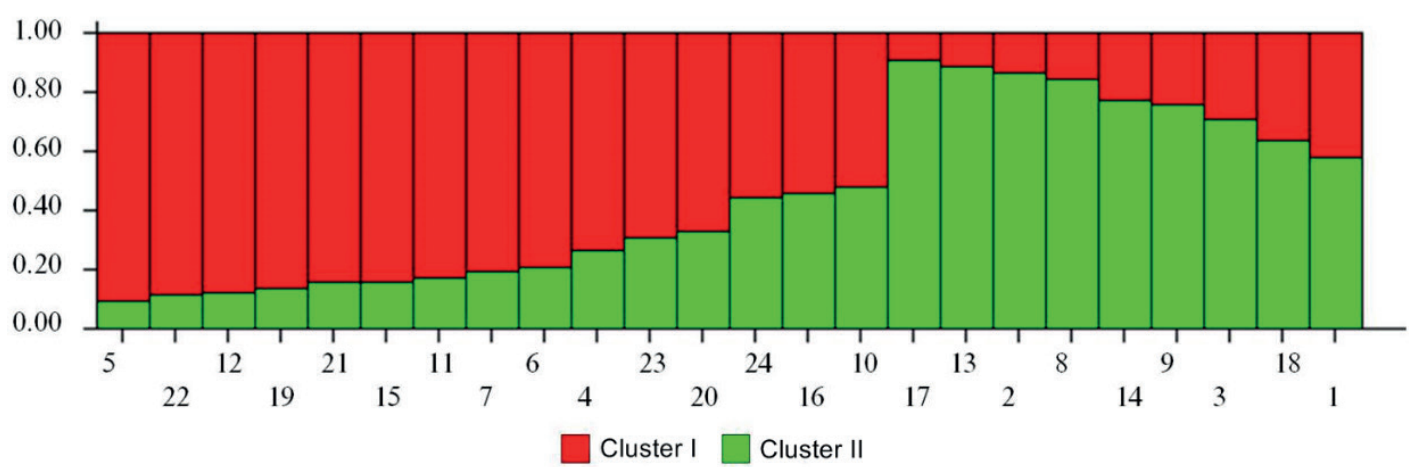


Table 2. Number of mother trees $(\mathrm{N})$ and genetic parameters for the two clusters $(K=2)$, as determined by the software Structure for 24 mangabeira mother trees.

\begin{tabular}{cccc}
\hline Parameters & Cluster I & Cluster II & Total \\
\hline $\mathrm{N}$ & 15 & 9 & 24 \\
$\mathrm{Na}$ & $1,35(0,48)$ & $1,49(0,50)$ & $1,58(0,50)$ \\
$\mathrm{Ne}$ & $1,21(0,33)$ & $1,32(0,39)$ & $1,29(0,33)$ \\
$\mathrm{He}$ & $0,12(0,19)$ & $0,18(0,21)$ & $0,18(0,18)$ \\
$\mathrm{I}$ & $0,19(0,27)$ & $0,27(0,30)$ & $0,27(0,27)$ \\
$\% \mathrm{P}$ & 35,09 & 49,12 & 57,89 \\
\hline
\end{tabular}

$\mathrm{N}$ : Number of mother trees, Na: Number of observed alleles, Ne: Number of effective alleles, He: Nei's genetic distance, I: Shannon diversity index, and \%P: Percentage of polymorphic loci. The numbers in parentheses represent the standard deviation.

Higher Nei's $(\mathrm{He})$ and Shannon $(I)$ genetic diversity indices were found for Cluster II $(\mathrm{He}=0.18$ and $I=0.27$ ) (Table 2). Despite having the lowest number of mother trees, this cluster also showed higher $\mathrm{Na}$ (1.49) and $\mathrm{Ne}$ (1.32) values than those of Cluster I. Therefore, the effects of genetic drift will be lower in this cluster. In small and isolated populations, the genetic drift may lead to a shortterm distancing of gene frequencies of the original population, resulting in losing alleles. As the time progresses, there may be an increase of inbreeding between related plants to avoid a greater probability of crossbreeding (KAGEYAMA et al., 1998).

The analysis of molecular variance (AMOVA) showed that the genetic variation happens more within $(83.39 \%)$ than among clusters (16.61\%), indicating that mangabeira is allogamous. Levels of genetic variation of allogamous species are theoretically high within populations and relatively low among populations (HAMRICK et al., 1992). These results corroborate some studies conducted with Cerrado tree species (SOARES et al., 2008; ZUCCHI et al., 2005). Darrault and Schlindwein (2005), studying the reproductive biology of mangabeira, identified a self-incompatibility mechanism that favors cross-pollination.

Mangabeiraisahighly-threatened fruittreespecies owing to a significant decrease in the ecosystem areas occupied by it in coastal zones (JIMENEZ et al., 2015) or in central Brazil (MOURA et al., 2011).
In this study, mother trees were found in grasslands and within road zones under a strong anthropic pressure, forming aggregates of individual plants isolated $2.1 \mathrm{~km}$ from each other. Such characteristics may restrict the movement of pollen and shortdistance seed dispersers, facilitating crossbreeding between neighboring plants and causing a further isolation between subpopulations (MOURA et al., 2011). In situ and ex situ conservation strategies are needed to promote the preservation of the remaining genetic variability.

\section{Conclusion}

ISSR primers identified a molecular polymorphism among mangabeira mother trees and may be used for genetic analysis to obtain information for development of conservation strategies and breeding programs, and for commercial use. Most of the genetic exchange happens within groups, providing evidence for the need of conserving various mother trees to preserve the genetic variability of the population.

\section{Acknowledgments}

This research was supported by Coordenação de Aperfeiçoamento de Pessoal de Nível Superior and Fundação de Amparo à Pesquisa do Estado de Mato Grosso. 


\section{References}

COSTA, D. F.; VIEIRA, F. A.; FAJARDO, C. G.; CHAGAS, K. P. T. Diversidade genética e seleção de iniciadores ISSR em uma população natural de mangaba (Hancornia speciosa Gomes) (Apocynaceae). Revista Brasileira de Fruticultura, Jaboticabal, v. 37, n. 4, p. 970-976, 2015.

CRUZ, C. D. GENES - a software package for analysis in experimental statistics and quantitative genetics. Acta Scientiarum Agronomy, Maringá, v. 35, n. 3, p. 271-276, 2013.

DARRAULT, R. O.; SCHLINDWEIN, C. Limited fruit production in Hancornia speciosa (Apocynaceae) and pollination by nocturnal and diurnal insects. Biotropica, Washington, v. 37, n. 3, p. 381-388, 2005.

DOYLE, J. J.; DOYLE, J. L. A rapid DNA isolation procedure for small quantities of fresh leaf tissue. Phytochemical Bulletin, Irvine, v. 19, n. 1, p. 11-15, 1987.

EARL, D. A.; VONHOLDT, B. M. STRUCTURE HARVESTER: a website and program for visualizing STRUCTURE output and implementing the Evanno method. Conservation Genetics Resources, Dordrecht, v. 4, n. 2, p. 359-361, 2012.

EVANNO, G.; REGNAUT, S.; GOUDET, J. Detecting the number of clusters of individuals using the software STRUCTURE: a simulation study. Molecular Ecology, Vancouver, v. 14, n. 8, p. 2611-2620, 2005.

EXCOFFIER, L.; LISCHER, H. E. L. Arlequin suite ver 3.5: a new series of programs to perform population genetics analyses under Linux and Windows. Molecular Ecology Resources, Oxford, v. 10, n. 3, p. 564-567, 2010.

FALEIRO, F. G. Marcadores genético-moleculares aplicados a programas de conservação e uso de recursos genéticos. Planaltina: Embrapa Cerrados, 2007. 102 p.

HAMRICK, J. L.; GODT, M. J. W.; SHERMANBROYLES, S. L. Factors influencing levels of genetic diversity in woody plant species. New Forest, Dordrecht, v. 6, n. 1, p. $95-124,1992$.

JIMENEZ, H. J.; MARTINS, L. S. S.; MONTARROYOS, A. V. V.; SILVA JUNIOR, J. F.; ALZATE-MARIN, A. L.; MORAES FILHO, R. M. Genetic diversity oh the Neotropical tree Hancornia speciosa Gomes in natural populations in Northeastern Brazil. Genetics and Molecular Research, Ribeirão Preto, v. 14, n. 4, p. 17749-17757, 2015.

KAGEYAMA, P. Y.; GANDARA, F. B.; SOUZA, L. M. I. Consequências genéticas da fragmentação sobre populações de espécies arbóreas. Série Técnica IPEF, Piracicaba, v. 12, n. 32, p. 65-70, 1998.
MOURA, N. F.; CHAVES, L. J.; VENKOVSKY, R.; NAVES, R. V.; AGUIAR, A. V.; MOURA, M. F. Genetic structure of mangaba (Hancornia speciosa Gomes) populations in the Cerrado Region of Central Brazil. Bioscience Journal, Uberlândia, v. 27, n. 3, p. 473-481, 2011.

OLIVEIRA, M. S. P.; SANTOS, J. B.; AMORIM, E. P.; FERREIRA, D. F. Variabilidade genética entre acessos de açaizeiro utilizando marcadores microssatélites. Ciência e Agrotecnologia, Lavras, v. 34, n. 5, p. 1253-1260, 2010.

PEREIRA, A. V.; PEREIRA, E. B. C.; SILVA JUNIOR, J. F.; SILVA, D. B. Mangaba. In: VIEIRA, R. F.; AGOSTINI-COSTA, T. S.; SILVA, D. B.; SANO, S. M.; FERREIRA, F. R. (Ed.). Frutas nativas da região Centro-Oeste do Brasil. Brasília: Embrapa Informação Tecnológica, 2010. p. 221-246.

PRITCHARD, J. K.; STEPHENS, M.; DONNELLY, P. Inference of population structure using multilocus genotype data. Genetics, Bethesda, v. 155, n. 1, p. 945959, 2000.

R CORE TEAM. R: a language and environment for statistical computing. Vienna: The R Foundation for Statistical Computing, 2016. Available at: <https:// www.r-project.org/>. Accessed at: 16 mar. 2016.

REDDY, M. P.; SARLA, N.; SIDDIQ, E. A. Inter simple sequence repeat (ISSR) polymorphism and its application in plant breeding. Euphytica, Wageningen, v. 128, n. 1, p. 9-17, 2002.

SILVA JUNIOR, J. F.; LÉDO, A. S. Botânica. In: SILVA JUNIOR, J. F.; LÉDO, A. S. (Ed.). A cultura da mangaba. Aracajú: Embrapa Tabuleiros Costeiros, 2006. p. 25-33.

SILVA, A. V. C.; RABBANI, A. R. C.; SENA-FILHO, J. G.; ALMEIDA, C. S.; FEITOSA, R. B. Genetic diversity analysus of mangaba (Hancornia speciosa Gomes), na exotic Brazilian tropical species. Tropical and Subtropical Agroecosystems, Mérida, v. 15, n. 1, p. 217-225, 2012.

SOARES, T.; CHAVES, L. J.; TELLES, M. P. C.; DINIZFILHO, J. A. F.; RESENDE, L. V. Distribuição espacial da variabilidade genética intrapopulacional de Dipteryx alata. Pesquisa Agropecuária Brasileira, Brasília, v. 43, n. 9, p. 1151-1158, 2008.

VAZ PATTO, M. C.; SATOVIC, Z.; PÊGO, S.; FEVEREIRO, P. Assessing the genetic diversity of Portuguese maize germoplasm using microsatellite markers. Euphytica, Wageningen, v. 137, n. 1, p. 63-72, 2004.

YEH, F. C.; YANG, R. C.; BOYLE, T. B. J.; YE, Z. H.; MAO, J. X. POPGENE, the user-friendly shareware 
for population genetic analysis. Edmonton: Molecular Biology and Biotechnology Centre, University of Alberta, 1997. Available at: <https://sites.ualberta. ca/ fyeh/popgene.html>. Accessed at: 10 jan. 2016.

ZUCCHI, M. I.; PINHEIRO, J. B.; CHAVES, L. J.;
COELHO, A. S. G.; COUTO, M. A.; MORAIS, L. K.; VENCOVSKY, R. Genetic structure and gene flow of Eugenia dysenterica natural populations. Pesquisa Agropecuária Brasileira, Brasília, v. 40, n. 10, p. 975$980,2005$. 
